\title{
Speech-language intervention in schizophrenia: an integrative review
}

Ana Paula Machado Goyano Mac-Kay ${ }^{(1)}$ Ivonne Mondaca Jerez ${ }^{(1)}$ Pía Monardez Pesenti ${ }^{(1)}$

Universidad Santo Tomás, Facultad de Salud,Viña del Mar - Chile.

Conflict of interests: Nonexistent

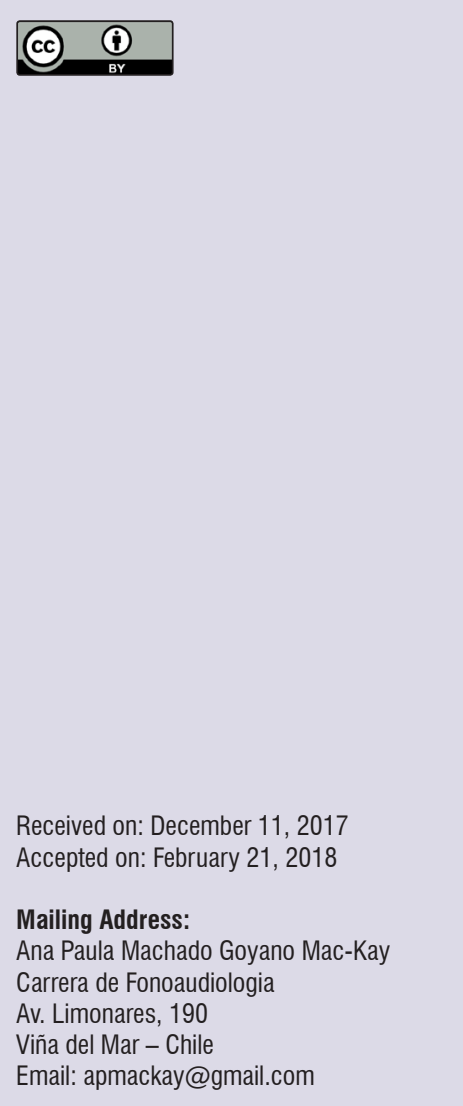

\section{ABSTRACT}

Objective: to perform an integrative review to identify speech and language pathology intervention for schizophrenia.

Methods: the review covered SCIELO, PUBMED, OXFORD JOURNALS and SCIENCEDIRECT databases for speech and language pathology intervention studies for schizophrenia. A narrative synthesis was adopted considering the level of clinical and methodological heterogeneity amid studies.

Results: the results demonstrated an increase in publications since 2012 with 11 articles meeting the criteria. Language and discourse assessment were the speech and language pathology privileged procedures.

Conclusion: the review indicates that the most eligible intervention was assessment, that studies' methodology were heterogeneous and that the communication disorders identified were related to discursive, pragmatic and syntactic disorders, which evidences the importance of more systematized intervention procedures and research on schizophrenic patients.

Keywords: Language; Schizophrenia; Speech; Mental Health; Communication; Speech, Language and Hearing Sciences 


\section{INTRODUCTION}

Speech and Language Pathology (SLP) studies the prevention, assessment and treatment of human communication disorders (oral and written language, voice, hearing and oral motor skills) ${ }^{1}$. The role played by the speech and language pathologist in Mental Health is based on performing specific procedures for evaluation, intervention, counseling and follow-up on the SLP disordered processes, creating strategies to promote and maintain patient's functional communication, a fundamental component of social interaction ${ }^{2}$.

Schizophrenia is a chronic mental disorder that has a multifactor etiology. Its global prevalence is $0.3 \%$ to $0.7 \%{ }^{3}$ and the incidence is higher in men though the definitions that include more mood symptoms and brief clinical events show an equivalent risk for both sexes ${ }^{3-5}$. The early symptoms occur usually between 15 and 45 years, often emerging at the beginning of youth (15-25 years) ${ }^{3}$.

The schizophrenic signs fall into two categories: positive and negative. Positive symptoms include disorders of perception (hallucinations), language, behavioural organization (severely disorganized or catatonic) and of thinking (delusional ideas) ${ }^{4-7}$. Positive symptoms include two dimensions that may be related to underlying neural mechanisms and different clinical correlations: the psychotic dimension, which comprehends delusions and hallucinations, and the disorganization dimension that compromises behavior and language. Negative symptoms are characterized by disorders of perception, inferential thinking, language and communication, behavior organization, affectivity, speech, hedonic capacity, will, motivation, attention and a decrease or loss of emotions. They also include restrictions on the intensity of emotional expression (affective flattening), on the fluency and productivity of thought and language (alogia) and on the initiation of goal-directed behavior (apathy) ${ }^{5-8}$. Negative symptoms are correlated to language poverty and worse social and occupational function? ${ }^{9}$.

The cognitive disorders in schizophrenia do not seem to be a consequence of the disorder itself, since there is no strong corresponding evidence between hallucinations or delusions severity with cognitive deficits severity. Attention and working memory problems are evident early and they do not recede even though the psychotic process is resolved, suggesting that there is no dependence on positive symptoms ${ }^{9}$. It has been established that attention deficits, which affect communication and language use, are observed before, during and after psychotic episodes and persist despite the attenuation effect of antipsychotic medication.

Communication disorders have been consistently considered as symptoms in the context of schizophrenia ${ }^{10}$, which implies a deficit of language comprehension and production (oral and written), pragmatic-discursive components and syntactic and semantic domains ${ }^{11}$. Patients with schizophrenia present semantic memory problems, that are evident in semantic priming and verbal fluency tests, deficits in word association, in the use of language, in the production of contextualized speech, in inferring context-dependent meanings and in social interaction 9,11-13. The discourse level attests to a lack of turn taking, discursive connectors and prosody alteration 10,13. Authors consider that the formal disorder of thought can include the decrease in the content of discourse, perseveration, echolalia, empty discourse and speech blockade because it implies a disconnection or detachment of communicative competence, failures in understanding the communicative context, failures in the use of grammatical links that allow a correct cohesion, an irregular speech and more difficulties in metaphor interpretation ${ }^{14,15}$.

Considering that SLP is a professional whose specialty is the study of normal and pathological processes of human communication ${ }^{1}$ then its practice collaborates to lead to the improvement of patient's quality of life since communication is essential for personal and social skills development and work integration.

It is relevant to analyze the scientific evidence on SLP praxis in schizophrenia for both clinical and research purposes, so the aim of this study was to synthesize the available evidence, which emphasizes SLP assessment and the therapeutic approach.

\section{METHODS}

This study was carried out with an integrative review to a qualitative approach of descriptive scope. The search for articles used the following databases: SCIELO, PubMed, OXFORD JOURNALS and SCIENCEDIRECT, It was conducted between September 2016 and April 2017, comprising of articles published from January 2000 to March 2017. The selection considered the following inclusion criteria: studies with topics covering one or more Speech and Language interventions, complete free access studies with sample of schizophrenic patients with ages in the 
range of 18 - 75 years, articles with abstract, quantitative or qualitative methodology or both and with description of SLP disorders. The exclusion criteria comprehended systematic reviews, samples of subjects with another psychiatric pathology associated, samples of subjects younger than 18 years and older than 75 years.

The search was performed in Spanish, English and Portuguese languages; the key words, obtained from the PubMed, used the following combinations: ((Speech \& Language Pathology AND Schizophrenia)) OR ((((Pragmatic AND Schizophrenia AND Speech \& Language Pathology))) OR (((Mental Health AND Schizophrenia AND Communication))) OR (( (Speech Language Treatment AND Schizophrenia))); ((Fonoaudiología AND Esquizofrenia)) OR (((Pragmatica AND Esquizofrenia AND Fonoaudiología))) OR (((Salud Mental AND Esquizofrenia AND Comunicación ))) OR ((Lenguaje AND Terapia AND Esquizofrenia)); (((Fonoaudiologia AND Esquizofrenia))) OR (((Pragmática AND Esquizofrenia AND Fonoaudiologia))) OR (((Saúde Mental AND Esquizofrenia AND Comunicação))) OR (((Linguagem AND Terapia AND Esquizofrenia))).
After applying the inclusion and exclusion criteria, articles were analyzed according to author, year of publication, type of SLP procedure, number of subjects in the sample, sex and results.

\section{RESULTS}

The initial search, with the keywords in English, Spanish and Portuguese, resulted first in 13,162 articles and in 8,648 after deleting the copies. Then, the process continued with refinement of the number of articles according to their title and relationship with the objective of the study, resulting in 1,198 articles. After the application of exclusion criteria, the sample dropped to 69 articles and with the application of inclusion criteria, to the final 11 articles. In a systematic review, authors found 18 articles but in their methodology there were different inclusion and exclusion criteria, a superior range of years and the incorporation of paid articles10. Figure 1 indicates the articles according to the language in which they were published and the country of origin of the study.

\begin{tabular}{|c|c|c|}
\hline \multirow{2}{*}{ Country } & \multicolumn{2}{|c|}{ Language } \\
\cline { 2 - 3 } & English & \\
\hline USA & 6 & \\
\hline Brazil & 2 & \\
\hline Italy & 1 & 1 \\
\hline Spain & & 1 \\
\hline Chile & & \\
\hline
\end{tabular}

Figure 1. Classification by language of publication and country of origin

According to the language in which the articles were written the results indicated 9 in English ${ }^{16-24}$ and 2 in Spanish ${ }^{25,26}$. In relation to the country of origin it was verified articles from United States of America 16-18,20-22, Brazil ${ }^{19.23}$, Italy ${ }^{24}$, Spain ${ }^{26}$ and Chile ${ }^{25}$. The investigations varied between individual case studies 18-20,25,26 and sample studies 16,17,21-24. Although the incidence of schizophrenia is greater in men ${ }^{17,27}$, in this review it was observed that only five articles specified the sex of participants $16,17,23,24,26$. The analyses of the articles characteristics are presented in Figure 2. 


\begin{tabular}{|c|c|c|c|c|c|}
\hline $\begin{array}{c}\text { Author and } \\
\text { year of } \\
\text { publication }\end{array}$ & SLP procedure & $\mathrm{N}^{\circ}$ subjects & $\begin{array}{c}\text { Sex } \\
\text { Females (F) } \\
\text { Males (M) }\end{array}$ & Results & Observations \\
\hline $\begin{array}{l}\text { Bosco et al. } \\
(2016) .\end{array}$ & $\begin{array}{l}\text { - Pragmatic communicative } \\
\text { skills (linguistic, extra linguis- } \\
\text { tic, paralinguistic). } \\
\text { - Conversational skills. } \\
\text { - Cognitive functions (aware- } \\
\text { ness, planning). } \\
\text { - Theory of the mind ToM. }\end{array}$ & 17 & $\begin{array}{l}10 \mathrm{M} \\
7 \mathrm{~F}\end{array}$ & $\begin{array}{l}\text { According to the results of the ABaCo protocol, a } \\
\text { significant improvement in post-training perfor- } \\
\text { mance was observed compared to the measure } \\
\text { in pre-training in comprehension and production } \\
\text { tasks. } \\
\text { The improvements were stable at all scales even } \\
\text { after } 3 \text { months from the end of the remediation } \\
\text { program, as shown by the comparison between } \\
\text { the scores on the linguistic, extra linguistic and } \\
\text { paralinguistic scales obtained in pre-training and } \\
\text { in the follow-up evaluation. } \\
\text { Neuropsychological and theory of mind tests } \\
\text { revealed no statistically significant difference } \\
\text { between performance before and after training. } \\
\text { These preliminary findings provide evidence of } \\
\text { the effectiveness of the Pragmatic Communicative } \\
\text { program in improving the pragmatic-communica- } \\
\text { tive skills of schizophrenic individuals. }\end{array}$ & $\begin{array}{l}\text { - Evaluation Battery for Com- } \\
\text { munication (ABaCo) in its } \\
\text { forms A and B. } \\
\text { - Battery of neuropsychologi- } \\
\text { cal tests: Attentive Matrices, } \\
\text { Trail making test, Verbal } \\
\text { Span, Spatial Span, Immedi- } \\
\text { ate and Deferred Recall test } \\
\text { for long-term verbal memory, } \\
\text { Tower of London, Modified } \\
\text { Card Sorting test, Raven's } \\
\text { Standard Progressive Matri- } \\
\text { ces, Aachener Aphasie test } \\
\text { (AAT) naming scale. } \\
\\
\text { - The theory of the mind was } \\
\text { evaluated through the story } \\
\text { of Sally and Ann and with } \\
\text { odd stories assignments. }\end{array}$ \\
\hline $\begin{array}{l}\text { Santos et al. } \\
\text { (2014) }\end{array}$ & $\begin{array}{l}\text { - Discourse } \\
\text { - Pragmatic inference. } \\
\text { - Semantic lexicon. } \\
\text { - Prosody. }\end{array}$ & 50 & $\begin{array}{l}26 \mathrm{M} \\
24 \mathrm{~F}\end{array}$ & $\begin{array}{l}\text { The communicative behavior of individuals diag- } \\
\text { nosed with schizophrenia is abnormal in every } \\
\text { aspect of language. } \\
\text { Among the aspect most affected was discourse } \\
\text { and pragmatics, which should also be related to } \\
\text { the characteristics of thinking and alterations of } \\
\text { cognition. } \\
\text { The prosodic components were the less changed } \\
\text { at the comprehension level; however, linguistic } \\
\text { production proved to be the most changed area. } \\
\text { The study participants showed greater difficulty in } \\
\text { expressing their emotions or repeating sentences } \\
\text { with different intonations. Considering these } \\
\text { conclusions, it should be noted that the speech } \\
\text { pathologist could contribute considerably in the } \\
\text { clinical care and formulation of intervention pro- } \\
\text { grams for patients diagnosed with schizophrenia. }\end{array}$ & $\begin{array}{l}\text { - The Montreal Battery for } \\
\text { Communication Evalua- } \\
\text { tion (abbreviated version) } \\
\text { was used to evaluate four } \\
\text { communicative processes: } \\
\text { discourse; pragmatics; se- } \\
\text { mantic lexicon; and prosody. }\end{array}$ \\
\hline $\begin{array}{l}\text { Docherty, } \\
\text { (2012). }\end{array}$ & $\begin{array}{l}\text { - Speech samples were evalu- } \\
\text { ated using scales selected } \\
\text { from the Thinking, Language } \\
\text { and Communication Scales } \\
\text { (TLC) } \\
\text { - Communication disorders } \\
\text { were classified using the } \\
\text { Communication Disturbance } \\
\text { Index (CDI). } \\
\text { - Sustained attention was } \\
\text { assessed by the cognitive } \\
\text { performance test (CPT-A) } \\
\text { and CPT-Identical Pairs test } \\
\text { (CPT-IP). } \\
\text { - Working memory was as- } \\
\text { sessed by the digit span test } \\
\text { and a computer version of the } \\
\text { Wisconsin Card Sorting Test } \\
\text { (WCST). }\end{array}$ & 60 & $\mathrm{~N} / \mathrm{A}$ & $\begin{array}{l}\text { Cognitive control task } \\
\text { The foundations of the cognitive process of } \\
\text { schizophrenic speech impairment are more easily } \\
\text { identifiable when the measure of speech disorder } \\
\text { is related to disordered thinking and disorganiza- } \\
\text { tion or deterioration of linguistic structure. } \\
\text { The neuropsychological tests were not directly } \\
\text { related to the speech disorder measured (disorder } \\
\text { of thought, disorganization or linguistic structur- } \\
\text { ing), but explained a significant proportion of the } \\
\text { variance in the speech disorder measured from } \\
\text { the perspective of communication failure. } \\
\text { The idea that communication failures in schizo- } \\
\text { phrenic patients' speech do not reflect psychotic } \\
\text { ideas, but evidences combinations of neuropsy- } \\
\text { chological disorders related to schizophrenia. } \\
\text { That said, most of the variance in schizophrenic } \\
\text { speech disorder remains unexplained. }\end{array}$ & $\begin{array}{l}\text { - The linguistic structural } \\
\text { disturbance was evaluated } \\
\text { using a method based on } \\
\text { Hoffman's work that exam- } \\
\text { ines the hierarchical relations } \\
\text { between the statements } \\
\text { in the narrative discourse. } \\
\text { (Hoffman et al, 1986). }\end{array}$ \\
\hline
\end{tabular}




\begin{tabular}{|c|c|c|c|c|c|}
\hline $\begin{array}{l}\text { Author and } \\
\text { year of } \\
\text { publication }\end{array}$ & SLP procedure & $\mathrm{N}^{\circ}$ subjects & $\begin{array}{c}\text { Sex } \\
\text { Females (F) } \\
\text { Males (M) }\end{array}$ & Results & Observations \\
\hline $\begin{array}{l}\text { Becker et al. } \\
\text { (2012). }\end{array}$ & $\begin{array}{l}\text { - Cognitive control task } \\
\text { - Discourse assessment. } \\
\text { - Speech } \\
\text { - Working Memory. }\end{array}$ & 45 & $\mathrm{~N} / \mathrm{A}$ & $\begin{array}{l}\text { Alogia is associated with the poor topic mainte- } \\
\text { nance and poor verbal working memory. } \\
\text { The association between disorganized speech } \\
\text { and poor topic maintenance suggests that disor- } \\
\text { ganized speech symptoms in schizophrenia can } \\
\text { be related to problems in maintaining a topic and } \\
\text { directing a continuous behavior. } \\
\text { The results suggest that alogia is not only related } \\
\text { to problems in the management of speech objec- } \\
\text { tives but also to problems in working memory } \\
\text { capacity. This indicates that people with alogia } \\
\text { may have problems initiating and producing } \\
\text { speech due to maintenance problems in working } \\
\text { memory. }\end{array}$ & $\begin{array}{l}\text { - Each participant partici- } \\
\text { pated in a semi-structured } \\
\text { interview of } 15 \text { to } 30 \text { minutes } \\
\text { that was recorded and tran- } \\
\text { scribed. During the interview } \\
\text { they were asked to provide } \\
\text { up to } 19 \text { memories. The first } \\
\text { memory was used for prac- } \\
\text { tice. Then, they were asked } \\
\text { to give six neutral memories, } \\
\text { six negative memories and } \\
\text { finally six positive memories. } \\
\text { - CDI scale measured disor- } \\
\text { ganized discourse. } \\
\text { - The CSS evaluated speech } \\
\text { deficit and confused thinking. } \\
\text { - N-back, POP (Preparation } \\
\text { to Overcome a Prepotent Re- } \\
\text { sponse), Running Memory } \\
\text { Span Task evaluated tasks of } \\
\text { cognitive control. }\end{array}$ \\
\hline $\begin{array}{l}\text { Docherty et al. } \\
\text { (2012). }\end{array}$ & $\begin{array}{l}\text { - Pre-morbid verbal intel- } \\
\text { ligence was estimated using } \\
\text { the vocabulary test of the } \\
\text { Shipley Life Scale Institute. } \\
\\
\text { - Sustained attention was } \\
\text { measured using the Con- } \\
\text { tinuous Performance-Identical } \\
\text { Pair Test (CPT-IP). } \\
\text { - The cognitive social tests } \\
\text { (that include evaluation of } \\
\text { prosody, facial expression and } \\
\text { body language) were: Eckman } \\
\text { test, Bell-Lysaker Emotion } \\
\text { Recognition Test (BLERT) } \\
\text { and the non-verbal sensitivity } \\
\text { profile (PONS- media-PONS). }\end{array}$ & $\begin{array}{l}84(21 \\
\text { in group } \\
\text { control) }\end{array}$ & $\mathrm{N} / \mathrm{A}$ & $\begin{array}{l}\text { The emotional alterations and problems related to } \\
\text { Theory of the Mind contribute to lack of commu- } \\
\text { nication in the discourse. } \\
\text { The results of the current study suggested that } \\
\text { the lack of communication in the speech of } \\
\text { patients with schizophrenia might be a natural } \\
\text { consequence of the limitations related to neuro- } \\
\text { cognitive and relational functioning. } \\
\text { Most participants had cognitive and social impair- } \\
\text { ments and some level of speech disorder. }\end{array}$ & \\
\hline $\begin{array}{l}\text { Berberian et al. } \\
(2009) .\end{array}$ & $\begin{array}{l}\text { - Auditory working memory } \\
\text { test (AWM) and the visual } \\
\text { work memory test (VWM) } \\
\text { were selected for working } \\
\text { memory evaluation. } \\
\text { - The computerized version of } \\
\text { Stroop was used to evaluate } \\
\text { selective attention. } \\
\text { - Semantics was evaluated } \\
\text { with the semantic generation } \\
\text { test. } \\
\text { - The executive functions were } \\
\text { evaluated through the Trail } \\
\text { Making Test }\end{array}$ & $\begin{array}{l}40 \text { (20 } \\
\text { included } \\
\text { in group } \\
\text { control) }\end{array}$ & $\mathrm{N} / \mathrm{A}$ & $\begin{array}{l}\text { - The executive functions showed a great dete- } \\
\text { rioration in subjects with schizophrenia when } \\
\text { compared to healthy controls. } \\
\text { - Cognitive dysfunction is a central feature of } \\
\text { schizophrenia and the possible main cause of } \\
\text { dysfunctional outcome in working memory and } \\
\text { semantics. } \\
\text { - Parametric analysis indicated auditory and } \\
\text { visual working memory alterations in patients } \\
\text { with schizophrenia. } \\
\text { - Selective attention reaction time was marginal, } \\
\text { which reveals a tendency in schizophrenia group } \\
\text { to require more time to respond to selective } \\
\text { attention tasks. }\end{array}$ & \\
\hline
\end{tabular}




\begin{tabular}{|c|c|c|c|c|c|}
\hline $\begin{array}{l}\text { Author and } \\
\text { year of } \\
\text { publication }\end{array}$ & SLP procedure & $\mathrm{N}^{\circ}$ subjects & $\begin{array}{c}\text { Sex } \\
\text { Females (F) } \\
\text { Males (M) }\end{array}$ & Results & Observations \\
\hline $\begin{array}{l}\text { Elvevåg et al. } \\
(2007) .\end{array}$ & $\begin{array}{l}\text { - Verbal Fluency. } \\
\text { - Semantics. } \\
\text { - Narrative discourse evalua- } \\
\text { tion (TLC). }\end{array}$ & $\begin{array}{l}51(25 \\
\text { included } \\
\text { in group } \\
\text { control) }\end{array}$ & $\mathrm{N} / \mathrm{A}$ & $\begin{array}{l}\text { - Through latent semantic analysis (LSA), in- } \\
\text { consistency was identified in different types of } \\
\text { schizophrenic patients discourse. } \\
\text { - It was shown that the LSA could detect an } \\
\text { Incoherent speech in patients with high levels } \\
\text { of formal mental disorder was detected by LSA } \\
\text { mainly in larger units of speech (more than } 5 \\
\text { words). } \\
\text { - The LSA can be applied successfully to the } \\
\text { model and measure semantic content expressed } \\
\text { through speech. }\end{array}$ & $\begin{array}{l}\text { - Verbal fluency was as- } \\
\text { sessed by requesting the } \\
\text { subjects to verbally generate } \\
\text { as many "animals" as they } \\
\text { could in a period of } 1 \text { min. } \\
\text { - Semantics was evaluated } \\
\text { by requesting the subject to } \\
\text { verbalize the first word that } \\
\text { came to mind when a group } \\
\text { of } 10 \text { words was read one } \\
\text { at a time. }\end{array}$ \\
\hline $\begin{array}{l}\text { Servat et al. } \\
(2005) \text {. }\end{array}$ & $\begin{array}{l}\text { - The functions of visual } \\
\text { perception, visual memory, } \\
\text { verbal fluency, motor func- } \\
\text { tion, speed of visual search, } \\
\text { mental flexibility, ability to } \\
\text { inhibit inappropriate re- } \\
\text { sponses, immediate memory } \\
\text { and numerical reasoning were } \\
\text { examined through the Benton } \\
\text { visual retention test, the Trail } \\
\text { Making Test (forms A and B), } \\
\text { the Stroop test, the controlled } \\
\text { association test of words and } \\
\text { the sub-tests of Digits and } \\
\text { Arithmetic of the WAIS }\end{array}$ & $\begin{array}{l}40(20 \\
\text { included } \\
\text { in group } \\
\text { control)) }\end{array}$ & $\mathrm{N} / \mathrm{A}$ & $\begin{array}{l}\text { - According to the results obtained, it can be } \\
\text { concluded that some altered functions appear in } \\
\text { the schizophrenic group while others maintain the } \\
\text { levels of functioning comparable to those of the } \\
\text { control group. } \\
\text { - Verbal fluency, auditory memory, numerical } \\
\text { reasoning and the ability to inhibit inappropriate } \\
\text { responses did not show significant differences } \\
\text { between schizophrenic patients and the control } \\
\text { group. }\end{array}$ & \\
\hline $\begin{array}{l}\text { Bowie et al. } \\
\text { (2004). }\end{array}$ & $\begin{array}{l}\text { - Evaluation of verbal episodic } \\
\text { memory. } \\
\text { - Evaluation of the percep- } \\
\text { tual organization and visual } \\
\text { memory. } \\
\text { - Semantic memory. } \\
\text { - Semantic fluency. } \\
\text { - Phonological fluency. } \\
\text { - Evaluation of thinking, lan- } \\
\text { guage and communication. }\end{array}$ & 392 & $\begin{array}{l}176 \mathrm{M} \\
216 \mathrm{~F}\end{array}$ & $\begin{array}{l}\text { - Patients with severe semantic and phonological } \\
\text { verbal fluency impairment showed deterioration } \\
\text { in verbal episodic memory test, perceptual orga- } \\
\text { nization, visual memory and language, in addition } \\
\text { to presenting worse functionality than patients } \\
\text { with intact or moderately impaired verbal fluency. } \\
\text { - The majority of patients with geriatric schizo- } \\
\text { phrenia demonstrated impairments in verbal flu- } \\
\text { ency tests, when age and educational level were } \\
\text { considered. The performance in tasks of seman- } \\
\text { tic and phonological fluency were related more to } \\
\text { cognitive factors than to negative symptoms. } \\
\text { - Phonological and semantic fluency was more } \\
\text { linked to functional status than to verbal memory, } \\
\text { which can be an important predictor. } \\
\text { - It was not evident that impaired verbal fluency } \\
\text { was predictive of the functional condition in } \\
\text { patients. } \\
\text { - More research is needed to understand the ben- } \\
\text { efits that can result from improving verbal fluency. }\end{array}$ & $\begin{array}{l}\text { Assessment was performed } \\
\text { with the the CERAD cognitive } \\
\text { battery supplemented by: } \\
\text { - Word list learning and } \\
\text { delayed recall. } \\
\text { - Praxic drawings. } \\
\text { - Modified Boston naming } \\
\text { test. } \\
\text { - Semantic fluency test, } \\
\text { (animals in one minute). } \\
\text { - Phonological fluency test } \\
\text { (words with f, a, s in one } \\
\text { minute). } \\
\text { - Evaluation of thought, } \\
\text { language and communica- } \\
\text { tion (TLC). } \\
\text { - Scale of social functioning } \\
\text { (SAFE). }\end{array}$ \\
\hline
\end{tabular}




\begin{tabular}{|c|c|c|c|c|c|}
\hline $\begin{array}{l}\text { Author and } \\
\text { year of } \\
\text { publication }\end{array}$ & SLP procedure & $\mathrm{N}^{\circ}$ subjects & $\begin{array}{c}\text { Sex } \\
\text { Females (F) } \\
\text { Males (M) }\end{array}$ & Results & Observations \\
\hline $\begin{array}{l}\text { Insúa, Gri- } \\
\text { jalvo y Huici } \\
\text { (2001), }\end{array}$ & $\begin{array}{l}\text { - Language Assessment. } \\
\text { - Verbal production. } \\
\text { - Discourse Semantic Orga- } \\
\text { nization. }\end{array}$ & $\begin{array}{l}21 \text { ( } 11 \\
\text { included } \\
\text { in control } \\
\text { group) }\end{array}$ & $\begin{array}{l}11 \mathrm{M} \\
10 \mathrm{~F}\end{array}$ & $\begin{array}{l}\text { - Assessment of language from the clinical point } \\
\text { of view, revealed few variations over time. } \\
\text { - Subjects with schizophrenia could have al- } \\
\text { tered "autonomous components of linguistic } \\
\text { processing" in addition to the deficits observed } \\
\text { in the pragmatic and macro-structural coding of } \\
\text { discourses what could have consequences in the } \\
\text { morphosyntax area. } \\
\text { - There are significant differences in speech } \\
\text { coherence between subjects with normal schizo- } \\
\text { phrenia and control. } \\
\text { - Subjects with schizophrenia presented distor- } \\
\text { tions and additional information, errors in the } \\
\text { order of events, inadequate connections and did } \\
\text { not present sufficient information for discursive } \\
\text { adequate comprehension. }\end{array}$ & $\begin{array}{l}\text { - TLC scale was used for } \\
\text { language clinical evaluation. } \\
\\
\text { - Psycholinguistic evaluation } \\
\text { using a test of verbal narra- } \\
\text { tion (the main episodes of } \\
\text { the "Pirate's Story") were } \\
\text { the basis for the analysis of } \\
\text { the psycholinguistic indexes } \\
\text { that operationalize the global } \\
\text { semantic organization of } \\
\text { discourse (textual macro- } \\
\text { structure. - Tests were ap- } \\
\text { plied at the beginning of the } \\
\text { study and then at } 9 \text { months, } \\
\text { without performing any type } \\
\text { of intervention. }\end{array}$ \\
\hline $\begin{array}{l}\text { Docherty et al. } \\
(2000) .\end{array}$ & $\begin{array}{l}\text { - Discourse evaluation. } \\
\text { - Attention. } \\
\text { - Immediate auditory memory. } \\
\text { - Sequence organization. }\end{array}$ & 26 & $\begin{array}{c}21 \mathrm{M} \\
5 \mathrm{~F}\end{array}$ & $\begin{array}{l}\text { - Communication deficits were identified; subjects } \\
\text { with schizophrenia presented disordered refer- } \\
\text { ences, omission of information, grammatical } \\
\text { alterations and difficulties with the meanings of } \\
\text { ambiguous words. } \\
\text { - There was an inability to preserve auditory } \\
\text { memory. } \\
\text { - Subjects presented alteration of organizational } \\
\text { sequences of discourse. } \\
\text { - Regarding sequence organization, two types of } \\
\text { disorders were verified: confusing references and } \\
\text { meanings of ambiguous words. }\end{array}$ & $\begin{array}{l}\text { - To obtain speech sample, } \\
\text { an interview was conducted; } \\
\text { participants were asked to } \\
\text { report negative memories, } \\
\text { which were recorded and } \\
\text { subsequently transcribed. } \\
\text { - To measure the disorga- } \\
\text { nized discourse, the CDI } \\
\text { scale was used. } \\
\text { - The CPT test was used to } \\
\text { evaluate attention. } \\
\text { - Digit spam was used to } \\
\text { evaluate the immediate audi- } \\
\text { tory memory. } \\
\text { - The trail making test form } \\
\text { B was used to evaluate } \\
\text { sequence organization. }\end{array}$ \\
\hline
\end{tabular}

Figure 2. Characteristics of selected studies

\section{DISCUSSION}

The main objective of this integrative review was to identify scientific evidence on the SLP intervention in schizophrenia and in the reviewed literature it was observed that the 11 selected studies favor the SLP evaluation over other interventions. They also indicate an increase in publications since 2012, with a greater number of research studies carried out in the United States. A variety of topics was observed such as those that discuss the effects of social cognition damage in language disorders ${ }^{20}$, the components of cognitive control and speech symptoms in people with schizophrenia ${ }^{21}$, the identification of the underlying processes of the disorder of schizophrenic speech ${ }^{22}$, the communicative behavior of subjects diagnosed with schizophrenia ${ }^{23}$ and the communicative-pragmatic treatment in schizophrenia ${ }^{24}$.

The methodology of the evaluations showed heterogeneity of designs. The most used tests were semantic and phonological fluency ${ }^{17,19,24,25}$ and the Trail Making Test part $A$ and part $B$ 16,19,24,25.

The procedure to evaluate language and communication in subjects with formal thought disorder was the Thought Disorders, Language and Communication Scale, which serves to identify speech and speech content poverty, distracted speech, tangentially, incoherence, neologisms and echolalia among others 17,18,22,26. The Index of Communication Disturbances (IDC), which measures and identifies the words or phrases with a confusing meaning and recognizes six types of errors (vague references, confusing references, lack of references in the information, 
ambiguous meanings of the word, incorrect use of the word and lack of structural clarity) was applied for the evaluation of the disorganized discourse 16,21,20 .

Consonant to the results, the importance of speech and language pathology treatment in subjects with schizophrenia is confirmed by the alterations detected in the evaluations. The most obvious symptoms were related to the semantic-pragmatic area, speech coherence, verbal fluency, prosody, attention, planning, sequencing and facial expression 16-22,25.

The reviewed studies suggest that cognitive deficits are associated with language poverty, alteration of speech and a worse social and occupational function 9,15 and also that the presence of cognitive dysfunction and executive functions directly or indirectly affect language and communication 16,19,24,25.

The pathological processes predisposing to schizophrenia are present early in life and the signs of social and language impairment are some of their nuclear characteristics ${ }^{13}$, a fact that indicates the importance of a prompt and, when possible, longitudinal Speech and Language Pathology intervention.

\section{CONCLUSION}

In accordance to the evidence given here, the present review demonstrates that there is a lack of research in SLP therapy in schizophrenia, given that no article covering treatment was found in this review. The study also identified a wide range of communication disorders, in various degrees, especially the areas related to incoherent language and grammatical alterations and evaluation as the most frequent procedure. The data indicates the need for further investigation of therapeutic practices in order to build a scientific evidence foundation for the benefit of the patient's quality of life. The information obtained serves as an argument for improvements in methodological homogeneity.

\section{REFERENCES}

1. Romero L. Displacements with respect to disciplinary knowledge of Speech, Language and Voice Therapist. Revista Chilena de Fonoaudiología. 2012;11:99-106.

2. Ramírez SA, Colina Matiz S. Papel del fonoaudiólogo en el área de salud mental: una experiencia profesional en el hospital militar central. Revista Med. 2009;17(1):26-33.
3. Herráez D, Palacios J. Recordatorio de semiología. Semiología de la esquizofrenia. Servicio de Psiquiatría. Hospital Infanta Sofía. San Sebastián de los Reyes. Madrid: No.1755, 2009.

4. American Psychiatric Association: Diagnostic and Statistical: Manual of Mental Disorders, Fifth Edition. Arlington: American Psychiatric Association, 2013.

5. Holder SD, Wayhs A. Schizophrenia. American Family Physician. 2014;90(11):775-82.

6. Musiol M, Rebuschi M. Rationality of inconsistency in schizophrenic conversation (Conversational pragmatical and formal semantic analysis). Psychologie Française. 2007;52(2):137-69.

7. Abdollhian E, Ghravi MM, Soltanifar A, Mokhber $N$. Relationship between positive and negative symptoms of schizophrenia and psychotic depression with risk of suicide. Iranian Journal of Psychiatry and Behavioral Sciences. 2009;3(1):27-32.

8. Almeida BPB, Cunha MC. Alterações da comunicação em pacientes institucionalizados portadores de esquizofrenia crônica. Rev. Soc. Bras. Fonoaudiol. 2011;16(1):117-8.

9. Barrera A. Cognitive deficits in schizophrenia. Revista Chilena de Neuro-Psiquiatría. 2006;44(3):215-21.

10. Joyal M, Bonneau A, Fecteau S. Speech and language therapies to improve pragmatics and discourse skills in patients with schizophrenia. Psychiatry Research. 2016;240:88-95.

11. Bordas C, Puyuelo M. Aspectos semánticos y pragmáticos en personas con esquizofrenia. Revista de Logopedia, Foniatría y Audiología. 2010;30(2):84-93.

12. Figueroa A. Análisis pragmalingüístico de los marcadores de coherencia en el discurso de sujetos con esquizofrenia crónica y de primer episodio [Tesis doctoral]. Valadolid (ES): Universidad de Valadolid, 2015. Disponible en: https://uvadoc. uva.es/ bitstream /10324/16539/1/ Tesis910-160314.pdf

13. Bambini V, Arcara G, Bechi M, Buono-core M, Cavallaro R, Bosia M. The communicative impairment as a core feature of schizophrenia: frequency of pragmatic deficit, cognitive substrates, and relation with quality of live. Compr Psychiatry. 2016;71:106-20.

14. McKenna $P$, Oh T. El lenguaje de los esquizofrénicos. Revista GU. 2005;1(3):229-32. 
15. Steinau S, Stegmayera K, Langb FU, Jagerb M, Strika W, Walthera S. Comparison of psychopathological dimensions between major depressive disorder and schizophrenia spectrum disorders focusing on language, affectivity and motor behavior. Psychiatry Research. 2017;250:169-76.

16. Docherty NM, Hall MJ, Gordinier S W, Cutting LP. Conceptual sequencing and disordered speech in schizophrenia. Schizophrenia Bulletin. 2000;26(3):723-35.

17. Bowie CR, Harvey PD, Moriarty PJ, Parrella M, White $\mathrm{L}$, Davis KL. A comprehensive analysis of verbal fluency deficit in geriatric schizophrenia. Archives of Clinical Neuropsychology. 2004;19(2):289-303.

18. Elvevág B, Foltz PW, Weinberger DR, Goldberg TE. Quantifying incoherence in speech: An automated methodology and novel application to schizophrenia. Schizophrenia research. 2007;93(1):304-16.

19. Berberian AA, Trevisan BT, Moriyama T S, Montiel JM, Oliveira JAC, Seabra AG. Working memory assessment in schizophrenia and its correlation with executive functions ability. Revista Brasileira de Psiquiatria. 2009;31(3):219-26.

20. Docherty $N$, McCleery A, Divilbiss M, Schumann EB, Moe A, Shakeel MK. Effects of social cognitive impairment on speech disorder in schizophrenia. Schizophrenia Bulletin. 2013;39(3):608-16.

21. Becker TM, Cicero DC, Cowan N, Kerns JG. Cognitive control components and speech symptoms in people with schizophrenia. Psychiatry Research. 2012;196(1):20-6.

22. Docherty NM. On identifying the processes underlying schizophrenic speech disorder. Schizophrenia Bulletin. 2012;38(6):1327-35.

23. Santos AED, Pedrão LJ, Zamberlan-Amorim NE, Carvalho AMP, Bárbaro AM. Communicative behavior of individuals with a diagnosis of schizophrenia. Rev. CEFAC. 2014;16(4):1283-93.

24. Bosco FM, Gabbatore I, Gastaldo L, Sacco K. Communicative-pragmatic treatment in schizophrenia: a pilot study. Front Psychol. 2016;7:166. doi:10.3389/fpsyg.2016.00166.

25. Servat P, Lehmann S, Harari A, Gajardo I, Eva C. Evaluación neuropsicológica en esquizofrenia. Revista Chilena de Neuro-Psiquiatria. 2005;43(3):210-6.

26. Insúa P, Grijalvo J, Huici P. Alteraciones del lenguaje en la esquizofrenia: Síntomas clínicos y medidas psicolingüísticas. Revista de la Asociación Española de Neuropsiquiatría. 2001;(78):27-50.

27. McGrath J, Saha S, Welham J, El Saadi O, MacCauley C, Chant D. A systematic review of the incidence of schizophrenia: the distribution of rates and the influence of sex, urbanicity, migrant status and methodology. BMC Medicine. 2004;2(1):1-22. 